\title{
ANALISIS EFISIENSI PENGGUNAAN MODAL KERJA PADA USAHA KECIL MENENGAH DI SURABAYA
}

\author{
Nekhasius Agus Sunarjanto ${ }^{1}$ \\ 1Jurusan Manajemen Universitas Katolik Widya Mandala Surabaya \\ Email : sunarjanto@ukwms.ac.id
}

\begin{abstract}
Building SMEs in order to be able to survive in an increasingly complex competitive environment is not easy, Business actors who have prepared themselves to compete will exist, but many failed entrepreneurs. Based on the findings of previous research, that the failure of SMEs business is largely determined by the capability of working capital management. Working capital management is to regulate the use of working capital according to business needs. The need for working capital is determined by the level of cash conversion cycle so it is necessary to take into account the turnover of each component in working capital. This study compares the use of working capital with working capital needs that must be met by the business, the use of working capital can be excessive, or lack. The excess or lack of working capital affects the inefficiency of the company in running the business, which eventually will go bankrupt
\end{abstract}

Keywords: Working capital, cash conversion cycle, working capital requirements, efficient use of working capital.

\begin{abstract}
ABSTRAK
Membangun UKM agar mampu untuk bertahan dalam kondisi persaingan yang semakin kompleks tidaklah mudah, Pelaku usaha yang telah mempersiapkan diri untuk berkompetisi akan eksis, tetapi banyak pula pengusaha yang gagal. Berdasarkan hasil temuan penelitian sebelumnya, bahwa kegagalan bisnis UKM sangat ditentukan oleh kemampuan pengelolaan modal kerja. Pengelolaan modal kerja adalah mengatur penggunaan modal kerja sesuai kebutuhan usaha. Kebutuhan modal kerja sangat ditentukan oleh tingkat siklus konversi kas sehingga perlu memperhitungkan tingkat perputaran dari masing masing komponen di dalam modal kerja. Penelitian ini membandingkan antara penggunaan modal kerja dengan kebutuhan modal kerja yang harus dipenuhi oleh usaha, penggunaan modal kerja bisa berlebihan, atau kekurangan. Kelebihan atau kekurangan modal kerja berdampak pada ketidak efisienan perusahaan dalam menjalankan usaha, yang pada akhirnya akan mengalami kebangkrutan

Kata kunci: Modal kerja, Siklus konversi kas, kebutuhan modal kerja, efisiensi penggunaan modal kerja.

\section{PENDAHULUAN}

\section{Latar belakang masalah}

Tujuan suatu usaha baik usaha berskala besar maupun kecil adalah mampu bertahan dan berkembang dalam waktu yang tidak terbatas, tetapi karakteristik usaha besar berbeda dengan UKM yang memiliki potensi risiko bisnis dan finansial yang relatif cukup besar. Pengelolaan UKM yang sederhana juga berkontribusi pada terhadap kegagalan usaha keberadaan usaha Kecil dan Menengah (UKM) merupakan kondisi kehidupan ekonomi sebagian besar masyarakat Indonesia. Dari 42,452 juta entitas usaha, ternyata 41,8 juta (98,5\%) merupakan usaha mikro. Hanya sekitar kurang lebih 650.000 yang merupakan usaha kecil dan menengah, serta sekitar kurang lebih 2.000 ribu lainnya adalah usaha besar (Menegkop, 2004). Angka ini meningkat pada tahun 2013 yaitu sebanyak lebih dari 50 juta UKM dengan kontribusi sebesar 56\% pada PDB. Posisi ini menempatkan usaha mikro, kecil dan menengah sebagai entitas utama dalam pemberdayaan ekonomi rakyat. Sementara itu karakteristik usaha besar berbeda dengan UKM
\end{abstract}


yang memiliki potensi risiko bisnis dan finansial yang relatif cukup besar. Pengelolaan UKM yang sederhana juga berkontribusi pada kegagalan usaha.

Hasil penelitian Sunarjanto, et al, 2016 menjelaskan bahwa tiga variabel yang dapat digunakan untuk memprediksi kegagalan keuangan bisnis UKM yaitu variable (modal kerja / total aset) dengan koefisien 4.0520 dan signifikan 0.0314, variabel (aset lancar / Kewajiban lancar) dengan koefisien 0.369247 dan signifikan 0.000, dan variabel ( quick aset / Inventory) dengan koefisien -0.743258 dan signifikan 0.000 , hal tersebut dapat menjelaskan bahwa pada bisnis UKM permasalahan utama adalah pengelolaan kas, piutang, persediaan dan pengelolaan kewajiban lancar, UKM belum mempertimbangakan análisis keterikatan dana, perputaran kas. Dari hasil análisis tersebut permasalahan utama bagi UKM adalah modal kerja , diindikasikan bahwa, penggunaan aktiva lancar tidak sesuai dengan kebutuhan modal kerja dan manajemen persediaan yang perlu diperbaiki, dampak dari permasalahan modal kerja ini mengakibatkan pada kelancaran aliran kas

Berdasarkan hasil temuan diatas nampak bahwa kegagalan bisnis UKM sangat ditentukan oleh kemampuannya pengelolaan modal kerja. Modal kerja merupakan unsur aktiva yang penting bagi perusahaan, jika dikendalikan dengan baik maka akan mendukung keberhasilan perusahaan, sedangkan jika kurang baik dalam pengelolaan dan perencanaan akan berakibat tidak saja kerugian tetapi juga bisa mengakibatkan dilikuidasinya perusahaan Oleh karena itu, pihak perusahaan harus lebih mencurahkan perhatiannya pada masalah modal kerja tersebut, sehigga diharapkan perusahaan dapat menggunakan modal kerja yang ada seefisien mungkin.

Dalam penentuan besar kecilnya modal kerja, perlu mempertimbangkan tingkat kegiatan perusahaan. Dimana tingkat kegiatan perusahaan dapat dilihat dari besar kecilnya penjualan dan tingkat kecepatan perputaran operasi perusahaan. Tingkat operasi perusahaan dapat tercermin melalui tingkat perputaran dari masing-masing unsur, yaitu kas, persediaan, surat berharga dan piutang yang terdapat dalam modal kerja itu sendiri. Untuk menentukan kebutuhan modal kerja, tentunya harus mengetahui dan menganalisis siklus konversi kas.

Pada dasarnya setiap usaha yang menjalankan usahanya sehari - hari selalu membutuhkan modal kerja. Modal kerja yang ada diharapkan mencakupi target atau standar yang telah direncanakan, sehingga modal kerja yang ada dipergunakan seefisien mungkin sehingga usaha mengalami kelebihan atau kekurangan modal kerja , kelebihan modal kerja akan berakibat menambah biaya bunga, sedangkan kekurangan modal kerja berakibat pada rendahnya likuiditas perusahaan dan hilangnya kesempatan untuk mendapatkan keuntungan , sehingga kekurangan atau kelebihan modal kerja berdampak pada beban perusahaan yang pada akhirnya menimbulkan kerugian usaha, dari permasalahan diatas maka peneliti ingin memecahkan permasalahan pada Usaha kecil dan menengah dengan melakukan penelitian dengan judul : Analisis Efisiensi Penggunaan Modal Kerja pada UKM di Surabaya

\section{Perumusan Masalah}

Apakah pengelolaan modal kerja pada UKM telah dilakukan secara efisien dengan mengatur penggunaan modal kerja sesuai dengan kebutuhan modal kerja

\section{Tujuan Penelitian}

Untuk mengetahui Apakah Pengelola modal kerja pada UKM telah dilakukan secara efisien dengan mengatur penggunaan modal kerja sesuai dengan kebutuhan modal kerja

\section{LANDASAN TEORI \\ Pengertian Modal Kerja}

Menurut J. Fred Weston dan Eugene F. Brigahm (Kutipan Agnes Sawir, 2003:129) menyatakan bahwa:"Modal kerja adalah investasi perusahaan didalam aktiva jangka pendek seperti kas, sekuritas (surat-surat berharga), piutang dagang dan persediaan". Menurut Burton A. Kolb (kutipan Agnes Sawir, 2003:129) mengemukakan bahwa:"Working capital is the investment of the firm in short-term or current assets, which includes cash,marketable securities, account

${ }^{1}$ Corresponding Author

Email: sunarjanto@ukwms.ac.id 
receivable, short-term notes receivales,inventories, and in some firms, expense prepayments. Dapat dijelaskan bahwa modal kerja adalah investasi perusahaan dalam aktiva jangka pendek atau lancar, termasuk didalamnya kas, sekuritas, piutang, persediaan, dan dalam beberapa perusahaan, biaya dibayar dimuka.

Sedangkan menurut Lukas Setia Atmaja (2003:365) mengemukakan bahwa: "Modal kerja atau working capital, sering pula disebut grossworking capital atau modal kerja kotor. Didefinisikan sebagai item-item pada aktiva lancar, yakni: (cash), sedangkan modal kerja bersih atau net working capital adalah aktiva lancar setelah dikurangi dengan hutang lancar".

\section{Siklus Konversi Kas}

Konsep siklus konversi kas diperkenalkan oleh Lawrence J. Gitman pada tahun 1974. Siklus konversi kas merupakan pengukuran dinamis terhadap manajemen likuiditas berjalan atau on going liquidity management (Jose et al., 1996) Jose et al. (1996) mengemukakan bahwa siklus konversi kas mengukur waktu antara pengeluaran kas untuk sumber daya dan penerimaan kas dari penjualan produk. Menurut Shin dan Soenen (1998), siklus konversi kas adalah pengukuran jumlah hari antara dana yang didedikasikan terhadap persediaan (inventory) dan piutang dagang (receivables) dikurangi jumlah hari pembayaran yang ditangguhkan kepada pemasok (supplier). Menurut Lukas Setia Atmaja "siklus konversi kas adalah waktu rata - rata antara penjualan kas untuk sumber daya produktif dengan penerimaan dari penjualan produk. Menurut Brealey et al., siklus konversi kas adalah periode antara pembayaran dari material dan mengumpulkan hasil penjualan. Siklus konversi kas juga dapat dikaitkan sebagai dana kas yang dipakai untuk menghasilkan produk atau membeli bahan mentah atau barang setengah jadi atau bahan jadi untuk selanjutnya diproses dan di jual kembali dengan harga yang jauh lebih menguntungkan dengan demikian keuntungan tersebut dapat digunakan untuk menambah kas pada perusahaan. Menurut Syarief dan Wilujeng (2009) mendefinisikan siklus konversi kas (SKK) sebagai waktu dalam satuan hari yang diperlukan untuk kas dari hasil operasi perusahaan yang berasal dari penagihan piutang ditambah penjualan ,persediaan dikurangi dengan pembayaran hutang. Formula untuk menghitung SKK menggunakan persamaan sebagai berikut:

$$
\begin{aligned}
& \text { SKK = DSO + DSI - DPO } \\
& \text { Keterangan: } \\
& \text { SKK = Siklus konversi kas } \\
& \text { DSO = Periode penerimaan piutang } \\
& \text { DSI = Periode konversi persediaan }
\end{aligned}
$$

\section{Efisiensi Modal Kerja}

Efisien manajemen modal kerja memainkan peran penting dari strategi perusahaan secara keseluruhan dalam rangka menciptakan nilai pemegang saham atau nilai perusahaan (Gitman and Zutter, 2012: 600). Efisiensi penggunaan modal kerja berarti tercapainya keseimbangan dalam investasi dan pendanaan modal kerja yang ideal (tidak lebih dan tidak kurang) (Charitou, 2012: 63). Pengelolaan modal kerja yang efisien memungkinkan sebuah perusahaan untuk bereaksi dengan cepat terhadap perubahan yang terjadi dalam lingkungan ekonomi dan mendapatkan keunggulan kompetitif atas para pesaingnya (Ching, et al, 2011 :74). Pemanfaatan modal kerja secara efisien karena adanya keyakinan bahwa tindakan ini memiliki pengaruh terhadap kinerja keuangan perusahaan secara keseluruhan dalam jangka panjang. Sebaliknya, perusahaan-perusahaan yang gagal dalam mengelola modal kerja akan terbawa dalam kondisi insolvency dan kesulitan keuangan (financial distress), bahkan bisa terjadi kebangkrutan. Efisiensi manajemen modal kerja bertujuan untuk memastikan keseimbangan yang optimal antara profitabilitas dan risiko. Tujuan ini dapat dicapai dengan pemantauan secara terus menerus dari komponen modal kerja seperti kas atau setara kas, piutang, persediaan dan utang. Bahkan efisiensi manajemen modal kerja adalah bagian mendasar dari strategi perusahaan 
secara keseluruhan dalam menciptakan nilai perusahaan (Deloof, 2003: 573). Metode Perhitungan Kebutuhan Dana untuk Modal Kerja. Penentuan kebutuhan modal kerja ada 3 (tiga) metode yang dapat dipergunakan untuk menghitung kebutuhan dana (financial needs) dari suatu bisnis, yaitu: Simple Method, Pro-forma Balance Sheet Method (Metode proyeksi neraca), dan Metode cash budget, dalam penelitian ini menggunakan metode Simple Method (metode sederhana). Sesuai namanya, perhitungan kebutuhan dana dilakukan dengan menggunakan rumus yang sangat sederhana.

$$
\begin{array}{ll}
\text { FN }=(\text { ART }+ \text { IT }- \text { APT }) \times C O G S \\
\text { Keterangan: } & \\
\text { FN }= & \text { Financial Needs (Kebutuhan Dana) } \\
\text { ART }= & \text { Account Receivable Turnover dalam bulan } \\
\text { IT }= & \text { Inventory Turnover dalam bulan } \\
\text { APT }= & \text { Account Payable Turnover dalam bulan } \\
\text { COGS }= & \text { Cost of Goods Sold untuk satu bulan }
\end{array}
$$

Rumus di atas hanya melihat sisi aktiva lancar, yakni piutang dagang (account receivable) dan persediaan (inventory), dan sisi kewajiban lancar, yaitu utang dagang (account payable).

\section{Hipotesis}

Pengelolaan modal kerja pada UKM belum dilakukan secara efisien ditunjukkan adanya perbedaan antara penggunaan modal kerja secara aktual dengan kebutuhan modal kerja yang seharusnya

\section{Kerangka Berpikir}

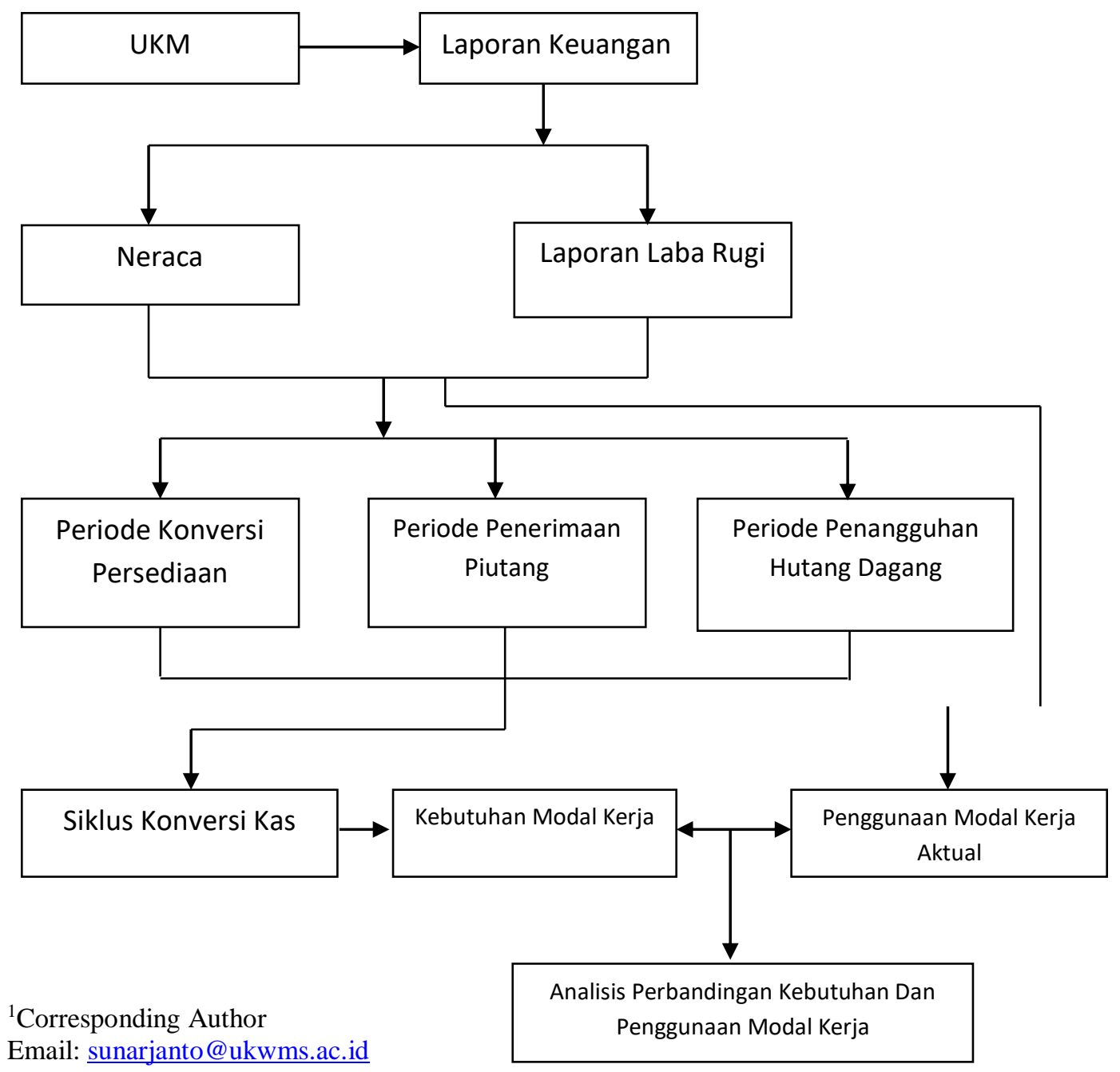


Gambar 1. Kerangka Berpikir

\section{METODE PENELITIAN}

\section{Desain Penelitian}

Penelitian ini merupakan penelitian empiris hipotesis yang digunakan untuk menguji beda antara penggunaan modal kerja aktual dengan kebutuhan modal kerja yang seharusnya selama periode $2009-2015$.

\section{Definisi Operasional Variabel}

a) Penggunaan Modal Kerja actual adalah total keseluruhan dari modal kerja yaitu penjumlahan kas + piutang + Persediaan atau keseluruhan aktiva lancer yang tercatat di neraca.

b) Efisiensi adalah perbandingan yang terbaik antara input (masukan) dan output (hasil antara keuntungan dengan sumber-sumber yang dipergunakan), seperi halnya juga hasil optimal yang dicapai dengan penggunaan sumber yang terbatas. Dibawah ini adalah rumus yang digunakan untuk mencari efisiesi yaitusebagai berikut:

Efesiensi $=$ Input Target $/$ Input Aktual $>=1$

c) Siklus Konversi Kas

Siklus konversi kas dapat dihitung berdasarkan periode konversi persediaan, periode penerimaan piutang danperiode penangguhan utang (Brigham dan Hauston, 2011:259262).

Rumus siklus konversi kas $=$ Periode konversi persediaan + periode penerimaan rata-rata piutang - periode penangguhan Hutang Dagang

Periode konversi persediaan $=$ Persediaan $/$ harga pokok penjualan $\times 365$

Periode Penerimaan rata - rata piutang $=$ Piutang/Penjualan $\times 365$

Periode Penangguhan Hutang $=$ Hutang Dagang /Harga Pokok Penjualan $\times 365$

d) Kebutuhan Modal Kerja

Dihitung dengan rumus:

Kebutuhan pendanaan Piutang $=$ (Rencana Penjualan $/ 365$ ) $\times$ Periode rata rata penerimaan piutang

Kebutuhan Pendanaan Persediaan $=($ Rencana HPP / 365 ) x Periode konversi persediaan

Kebutuhan Pembayaran $=($ Hpp kedepan / 365) $x$ Periode penangguhan Hutang

Kebutuhan Modal Kerja $=($ Kebutuhan Pendanaan Piutang + Kebutuhan Pendanaan Persediaan ) - Kebutuhan Pembayaran

\section{Teknik Analisis Data}

Teknik analisis data dalam penelitihan ini adalah menggunakan uji beda sebagai dengan rumus sebagai berikut ;

$$
t_{1-2}=\frac{\bar{X}_{1}-\bar{X}_{2}}{\sqrt{\left[\frac{S D_{1}{ }^{2}}{n_{1}-1}\right]+\left[\frac{S D_{2}^{2}}{n_{2}-1}\right]}}
$$

\section{Pengujian Hipotesis}

$\mathrm{H}_{0}: \mathrm{b}_{1}, \mathrm{~b}_{2}, \mathrm{~b}_{3}=0$, berarti tidak ada perbedaan yang signifikan antara penggunaan modal kerja actual dengan analisis kebutuhan modal kerja yang seharusnya. 
Analisis Efisiensi Penggunaan Modal Kerja Pada Usaha Kecil Menengah di Surabaya

$\mathrm{H}_{1}: \mathrm{b}_{1}, \mathrm{~b}_{2}, \mathrm{~b}_{3} \neq \mathbf{0} \quad$ berarti ada perbedaan yang signifikan antara penggunaan modal kerja actual dengan analisis kebutuhan modal kerja yang seharusnya 


\section{ANALISIS DAN PEMBAHASAN \\ Deskripsi dan Analisis Data}

Penelitian ini menggunakan data dari tahun 2009 hingga 2016 yang disebarkan ke sekitar 250 UMKM yang terdaftar di Dinas Koperasi dan UMKM serta dinas Perindustrian dan perdagangan Pemerintah Kota Surabaya. Namun hanya 50 UMKM yang memenuhi kualifikasi ketersediaan data untuk diolah, sehingga dengan cros section terkumpul 400 data yang dapat dianalisis, UMKM tersebut tidak menghendaki nama tidak dimunculkan. Berikut gambaran skala usaha UMKM berdasarkan aset yang dimiliki.

Tabel 1. Kriteria UMKM berdasarkan Aset

Descriptive Statistics

\begin{tabular}{|l|l|l|l|l|l|}
\hline & & Minimum & Maximum & Mean & Std. Deviation \\
\hline Total Aset & 400 & $2.40 \mathrm{E} 5$ & $1.60 \mathrm{E} 6$ & $7.0992 \mathrm{E} 5$ & $2.26989 \mathrm{E} 5$ \\
Valid N (listwise) & 400 & & & & \\
\hline
\end{tabular}

Bersadarkan Tabel 1 nampak bahwa profil UMKM yang diteliti rata rata memliki total aset sebesar Rp 709.920.000, terendah sebesar Rp 240.000.000 dan tertinggi sebesar Rp 1.600.000.000 dengan demikian maka sampel penelitian adalah usaha kecil dan menengah ( UKM) mengingat berdasarkan ketentuan pemerintah UU pasal 6 No. 20 tahun 2008 tentang UMKM, skala usaha berdasar kriteria Usaha Kecil yaitu memiliki kekayaan bersih lebih dari Rp 50.000.000,00 (lima puluh juta rupiah) sampai dengan paling banyak Rp 500.000.000,00 (lima ratus juta rupiah) tidak termasuk tanah dan bangunan tempat usaha dan kriteria Usaha Menengah jika memiliki kekayaan bersih lebih dari Rp 500.000.000,00 (lima ratus juta rupiah) sampai dengan paling banyak Rp 10.000.000.000,00 (sepuluh milyar rupiah) tidak termasuk tanah dan bangunan tempat usaha. Rata-rata sampel memiliki kekayaan sebesar 709.920.000 sehingga termasuk kelompok usaha Menengah.

\section{Deskripsi data}

a. Penggunaan Modal Kerja aktual

Modal kerja aktual adalah modal yang digunakan untuk kegiatan operasional menurut Bambang Riyanto , modal kerja dibedakan menjadi 2, yaitu : modal kerja bersih dan modal kerja kotor, modal kerja bersih adalah keseluruhan dari aktiva lancar dikurangi oleh hutang lancar, sedangkan modal kerja kotor adalah keseluruhan dari aktiva lancar, dalam penelitian ini dianalisis besarnya modal kerja bersih dan modal kerja kotor dapat dilihat pada tabel 2 dibawah ini.

Tabel 2. Modal Kerja

\begin{tabular}{|l|l|l|l|l|l|}
\hline & $\mathrm{N}$ & Minimum & Maximum & Mean & Std. Deviation \\
\hline Modal kerja bersih & 350 & $1.08 \mathrm{E} 5$ & $9.50 \mathrm{E} 5$ & $3.7429 \mathrm{E} 5$ & $1.73197 \mathrm{E} 5$ \\
Modal kerja kotor & 350 & $1.59 \mathrm{E} 5$ & $1.09 \mathrm{E} 6$ & $4.6335 \mathrm{E} 5$ & $1.97793 \mathrm{E} 5$ \\
\hline
\end{tabular}

Pada tabel 2. Tampak bahwa besarnya modal kerja bersih aktual yang dikeluarkan rata rata sebesar Rp 374.290.000, tertinggi sebesar Rp 950.000.000 dan terendah Rp 109.000.000, sedangkan modal kerja kotor atau keseluruhan dari aktiva lancar yang sesungguhnya dikeluarkan untuk kegiatan operasional rata rata sebesar Rp 463.350 .000 , tertinggi sebesar Rp 
1.090.000.000 dan terendah sebesar Rp 159.000.000 dari data tersebut dapat dianalisis bahwa titik terendah dan tertinggi jaraknya terlalu jauh, artinya bahwa dalam penelitian ini jenis industrinya sangat beragam, mulai dari industry yang membutuhkan modal kerja kecil sampai dengan industry yang menghasilkan modal kerja yang besar, karena penelitian ini lebih memfokuskan pada perusahaan yang menyediakan data keuangan, tanpa membedakan jenis industri

b. Analisis Kebutuhan Modal Kerja

Menghitung kebutuhan modal kerja, dalam penelitian ini menggunakan Siklus Konversi Kas. Menurut Syarief dan Wilujeng (2009) mendefinisikan siklus konversi kas (SKK) sebagai waktu dalam satuan hari yang diperlukan untuk kas dari hasil operasi perusahaan yang berasal dari penagihan piutang ditambah penjualan ,persediaan dikurangi dengan pembayaran hutang. Dari hasil analisis perhitungan pada tabel 3. tampak besarnya kebutuhan modal kerja sbb:

Tabel 3. Kebutuhan modal kerja

\begin{tabular}{|l|l|l|l|l|l|}
\hline & $\mathrm{N}$ & Minimum & Maximum & Mean & Std. Deviation \\
\hline $\begin{array}{l}\text { Kebutuhan modal kerja } \\
\text { Valid N (listwise) }\end{array}$ & 350 & $-7.8351 \mathrm{E} 4$ & $5.1684 \mathrm{E} 5$ & $1.457875 \mathrm{E} 5$ & $8.6147249 \mathrm{E} 4$ \\
\hline
\end{tabular}

Kebutuhan modal kerja rata rata sebesar $\mathrm{Rp} 145.787 .500$ dengan tertinggi sebesar $\mathrm{Rp}$ 516.840 .000 , jika dibandingkan dengan besarnya modal kerja bersih yang sesungguhnya ataupun modal kerja kotor yang sesungguhnya , besarnya kebutuhan modal kerja lebih kecil

c. Analisis Kebutuhan Pihutang

Kebutuhan pendanaan Piutang dihitung dengan rumus Rencana Penjualan / 365) x Periode rata rata penerimaan piutang, dianalisis menghasilkan tabel 4.4. dibawah ini:

Tabel 4. Kebutuhan Pihutang

\begin{tabular}{|l|l|l|l|l|l|}
\hline & N & Minimum & Maximum & Mean & $\begin{array}{l}\text { Std. } \\
\text { Deviation }\end{array}$ \\
\hline $\begin{array}{l}\text { Kebutuhan } \\
\text { Pihutang }\end{array}$ & 350 & 20699.77 & $3.24 \mathrm{E} 5$ & $1.1776 \mathrm{E} 5$ & 51736.67930 \\
\hline
\end{tabular}

Kebutuhan pihutang rata rata sebesar $\mathrm{Rp} 117.760 .000$, dengan terendah sebesar $\mathrm{Rp}$ 20.699.770 dan tertinggi Rp 324.000.000

d. Analisis Kebutuhan Persediaan

Kebutuhan Pendanaan Persediaan adalah dihitung dari besarnya Rencana HPP / 365 x Periode konversi persediaan, dari hasil SPSS dapat dilihat pada tabel 5 dibawah ini Tabel 5. Kebutuhan Persediaan

\begin{tabular}{|l|l|l|l|l|l|}
\hline & $\mathrm{N}$ & Minimum & Maximum & Mean & $\begin{array}{l}\text { Std. } \\
\text { Deviation }\end{array}$ \\
\hline $\begin{array}{l}\text { Kebutuhan } \\
\text { persediaan }\end{array}$ & 350 & 21424.90 & $4.80 \mathrm{E} 5$ & $1.3657 \mathrm{E} 5$ & 66732.27884 \\
\hline
\end{tabular}

Pada tabel 5 diatas dapat dijelaskan bahwa rata rata kebutuhan persediaan sebesar Rp 136.570.000 dengan terendah sebesar Rp 21.424.900 dan tertinggi sebesar Rp 480.000.000

e. Analisi Kebutuhan Pembayaran

Kebutuhan Pembayaran dihitung dengan rumus = (Rencana Hpp kedepan / 365) x Periode penangguhan Hutang, setelah dihitung, kemudian di analisis diskriptif dengan program SPSS menghasilkan pada tabel 6

Tabel 6. Kebutuhan Pembayaran

\begin{tabular}{|l|l|l|l|l|l|}
\hline & $\mathrm{N}$ & Minimum & Maximum & Mean & $\begin{array}{l}\text { Std. } \\
\text { Deviation }\end{array}$ \\
\hline $\begin{array}{l}\text { Kebutuhan } \\
\text { Pembayaran }\end{array}$ & 350 & 21598.86 & $2.33 \mathrm{E} 5$ & $9.0727 \mathrm{E} 4$ & 41405.09054 \\
\hline
\end{tabular}

${ }^{1}$ Corresponding Author

Email: sunarjanto@ukwms.ac.id 
Pada tabel 6 dapat dijelaskan bahwa kebutuhan pembayaran rata rata sebesar Rp 90.727.000 tertinggi sebesar Rp 233.000.000 dan terendah sebesar Rp 21.598.860

\section{f. Efisiensi Modal Kerja}

Efisiensi adalah perbandingan analisis kebutuhan modal dengan Modal kerja bersih atau kotor aktual, jika lebih besar satu maka dikatakan efisien, tetapi jika lebih kecil satu dikatakan tidak efisien, dalam penelitian ini menghitung antar analisis kebutuhan modal kerja dibagi dengan kebutuhan modal kerja kotor, kemudian hasilnya dianalisis dengan analisis diskriptif dengan menggunakan program SPSS, dapat dilihat pada tabel 7 dibawah ini

Tabel 7. Efisiensi modal kerja

\begin{tabular}{|l|l|l|l|l|l|}
\hline & $\mathrm{N}$ & Minimum & Maximum & Mean & $\begin{array}{l}\text { Std. } \\
\text { Deviation }\end{array}$ \\
\hline Efisiensi & 350 & -.28 & .65 & .3177 & .14606 \\
\hline $\begin{array}{l}\text { Valid } \\
\text { (listwise) }\end{array}$ & 350 & & & & \\
\hline
\end{tabular}

Pada Tabel 7 diatas dapat dijelaskan bahwa rata rata efisiensi sebesar 0.3177 dengan tertinggi sebesar 0.65 dan terendah -0.28 sehingga dapat jelaskan bahwa penggunaan modal kerja tidak efisien

\section{Pengujian Hipotesis}

Untuk menguji hipotesis apakah ada perbedaan yang signifikan antara penggunaan modal kerja aktual dengan analisis kebutuhan modal kerja yang seharusnya, menggunakan uji t berpasangan ( paired sample t Test) dapat dilihat pada tabel dibawah ini

Tabel 8. Paired Samples Statistics

\begin{tabular}{|l|l|l|l|l|}
\hline & Mean & $\mathrm{N}$ & Std. Deviation & Std. Error Mean \\
\hline Pair 1 Modal kerja kotor & $4.6335 \mathrm{E} 5$ & 350 & $1.97793 \mathrm{E} 5$ & 10572.47306 \\
Kebutuhan modal kerja & $1.457875 \mathrm{E} 5$ & 350 & $8.6147249 \mathrm{E} 4$ & $4.6047642 \mathrm{E} 3$ \\
\hline
\end{tabular}

Pada tabel 8 diatas menunjukkan selisih antara penggunaan modal kerja kotor yang aktual dengan analisis kebutuhan modal kerja sebesar 463.350.000 - 145.787.500 $=317.562 .500$, dari hasil tersebut menunjukkan bahwa mempunyai selisih sangat besar, sehingga penggunaan modal kerja melebihi kebutuhan modal kerja, hal ini bisa terjadi karena pengusaha kurang memahami keterikatan dana pada masing masing unsur modal kerja, sehingga meskipun bukan kebutuhan modal kerja , tatapi pengusaha tetap mengalokasikan dananya pada unsur unsur modal kerja

Tabel 9. Paired Test

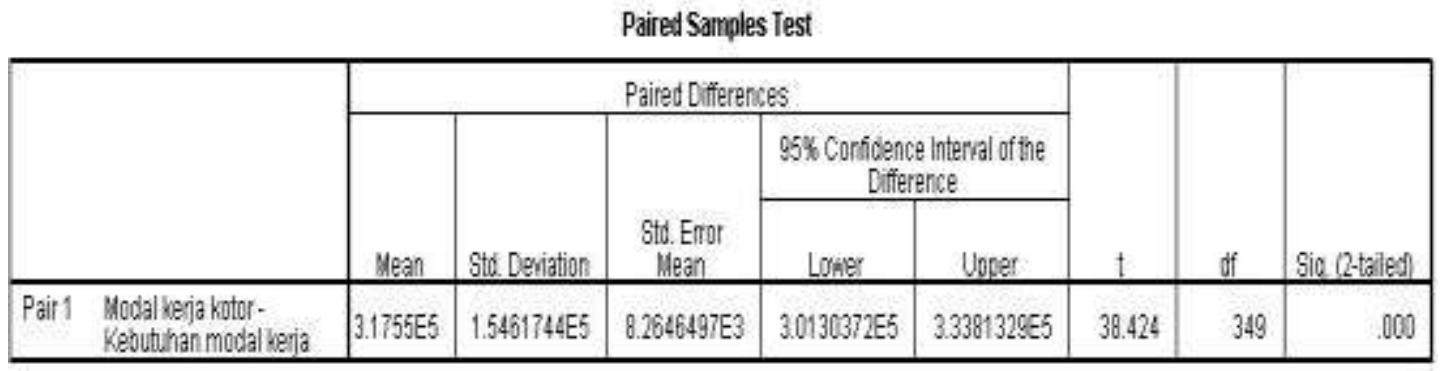


Pada tabel 9 diatas menunjukkan uji beda menggunakan uji t berpasangan (paired samlpes $t$ Test) untuk menguji hitotesis $\mathrm{H}_{0}: \mathrm{b}_{1}, \mathrm{~b}_{2}, \mathrm{~b}_{3}=0$, berarti tidak ada perbedaan yang signifikan antara penggunaan modal kerja aktual dengan analisis kebutuhan modal kerja yang seharusnya, menghasilkan nilai $t=38.424$ dengan significant 0.000 , lebih kecil dari 0.05 , sehingga Ho ditolak, sehingga ada perbedaan antara penggunaan modal kerja kotor aktual dengan analisis kebutuhan modal kerja.

\section{Pembahasan}

Berdasarkan temuan diatas bahwa uji t menunjukkan bahwa penggunaan modal kerja pada Usaha kecil menengah ada perbedaan antara penggunaan modal kerja kotor dengan kebutuhan modal kerja, sehingga dapat dikatakan bahwa penggunaan modal kerja tersebut tidak efisien dengan ditunjukkan bahwa rata rata efisiennya sebesar 0,3177 .

Ketidak efisienanan tersebut disebabkan karena tidak sesuai antara kebutuhan modal kerja dengan penggunaan modal kerja, dalam hal ini hasil analisis menunjukkan bahwa penggunaan modal kerjanya lebih besar dari pada kebutuhannya , hal ini dapat dilihat pada tabel dibawah ini.

Tabel . 10. Perbandingan Kebutuhan dan Penggunaan

\begin{tabular}{lll}
\hline & Rata-rata & Rata-rata Penggunaan / \\
& Kebutuhan & Pengalokasian \\
\hline Kas & 90.727 .000 & 528.000 .000 \\
Pihutang & 117.760 .000 & 133.520 .000 \\
Persediaan & 136.570 .000 & 114.260 .000 \\
\hline \multicolumn{2}{c}{ Sumber: Data diolah }
\end{tabular}

Pada tabel 10. dapat dijelaskan bahwa unsur modal kerja yang terdiri dari kas, pihutang dan persediaan menunjukkan bahwa ada kelebihan dalam penggunaan modal kerja, terutama dalam pengelolaan kas, sangat tidak efisien, seharusnya perusahaan menyiapkan jumlah kas sesuai dengan kebutuhan, sedangkan dalam pengelolaan persediaan sangat efisien, karena penggunaan dana untuk persediaan lebih kecil dari rata rata kebutuhannya, hal ini karena perusahaan tidak menyimpan bahan baku yang berlebihan atau menggunakan sistem langsung pesan

\section{KESIMPULAN DAN SARAN Kesimpulan}

Ada perbedaan yang signifikan antara penggunaan modal kerja aktual dengan analisis kebutuhan modal kerja yang seharusnya, menghasilkan nilai $t=38.424$ dengan significant 0.000, lebih kecil dari 0.05, sehingga Ho ditolak, sehingga ada perbedaan antara penggunaan modal kerja kotor aktual dengan analisis kebutuhan. Penggunaan modal kerja pada Usaha Kecil Menengah disurabaya, belum efisisien, hal dapat dilihat pada analisis diskriptif ( tabel 7 ) dijelaskan bahwa rata rata efisiensi modal kerja sebesar 0.3177 .

\section{Saran}

Perusahaan seharusnya membuat membuat estimasi penjualan, sehingga dengan kebutuhan modal dapat dihitung

\section{DAFTAR PUSTAKA}

Agnes, Sawir 2005.Analisis Kinerja Keuangan dan Perencanaan Keuangan Perusahaan.Edisi kelima.Jakarta:PT Gramedia Pustakan Utama.

Afeef, Mustafa. 2011.Analyzing the Impact of Working Capital Management on the Profitability of SME's in Pakistan. International Journal of Business and Social Science. Vol. 2 No. 22: 173 - 183.

Akinleye, G.T., Afolabi A.A. and Olowoniyi A.O. 2012. Working Capital Management and Profitability of Listed Companies in Nigeria. European Journal of Social Science, Vol 34 No. 4 : $595-602$. 
Alavinasab, Seyed Mohammad and Davoudi, Esmail. 2013. Studying The Relationship between Working Capital Management and Profitability Of Listed Companies in Tehran Stock Exchange. Business Management Dynamics, Vol.2, No.7 : 01-08.

Ashraf, Christi Khalid. 2012. The Relationship between Working Capital Efficiency and Profitability. Advanced in Management, Vol 5 (12) : 60 - 74.

Azhar, Nor Edi binti Mohammad and Noriza, binti Mohd Saad. 2010. Working Capital Management: The Effect of Market Valuation and Profitability in Malaysia.International Journal of Business and Management, Vol 5, No. $11: 140$ - 147.

Breatley, et al. 2007, Dasar - dasar manajemen Keuangan. Jakarta, Penerbit Erlangga

Brigham, Eugene F dan Houston, Joel F. 2006. Dasar-DasarManajemen Keuangan.Penerjemah Ali AkbarYulianto. Jakarta: Salemba Empat

Charitou, Melita., Petros Lois and Halim Budi Santoso. 2012. The Relationship between Working Capital Management and Firm's Profitability: An Empirical Investigation for An Emerging Asian Country. International Business \& Economics Research Journal, Vol 11, Number $8: 839$ - 848.

Ching, Hong Yuh, Ayrton Novazzi, and Fábio Gerab. 2011. Relationship Between Working Capital Management And Profitability In Brazilian Listed Companies. Journal Of Global Business And Economics, Volume 3. Number 1: $74-86$.

Deloof, M. 2003. Does Working Capital Management Affect Profitability of Belgian Firms Journal of Business, Finance and Accounting, Vol. 30, Nos. 3-4 :573-587.

Eljelly, A.M.A. 2004. Liquidity-Profitability Tradeoff: An Empirical Investigation in an Emerging Market. International Journal of Commerce and Management, Vol. 14, No. 2 : 48-61.

Falope, Olufemi I. and Ajilore, Olubanjo T. 2009. Working Capital Management and Corporate Profitability: Evidence from Panel Data Analysis of Selected Quoted Companies in Nigeria. Research Journal of Business Management, 3 (3) : 73 - 84.

Gitman, Lawrence J. and Zutter, Chad J. 2012. Principles of Managerial Finance, $13^{\text {th }}$ Edition, Prentice Hall.

Horne, Van James C and Wachowicz John M. 2009. Prinsip-prinsip Manajemen Keuangan.Penerjemah Dewi Fitriasari, S.S, M.Si, Ak dan Deny Arnos Kwary, M.Hum. Jakarta: Salemba Empat.

Ibnu Subianto, 2000, Metodologi Penelitian, edisi 3, Yogyakarta, Penerbit UPP AMP YKPN.

Lukas Setia Atmaja, 2013, Manajemen Keuangan , Jogjakarta: Penerbit Andi

Megginson, W.L., (1997), Corporate Finance Theory, Addison-Wesley.

Merton, R.C. (1974), 'On the Pricing of Corporate of Interest Rates', The Journal of Finance, 29(2) : 449-470.

Poza, E. (2004), Family Business, Thomson South-Western Publishing, Mason: Ohio.

Riyanto, B. (1995), Dasar-Dasar Pembelajaran Perusahaan, Yoyakarta: Yayasan Badan Penerbit Gadjah Mada

Ross, S.A., Westefild, R., and Jaffe, J. (2010), Corporate Finance, 9th Edition, McGraw Hill/Irwin Series.

Watson, J.E. (1993), 'Defining Small Business Failure', International Small Business Journal, 3(11): 35-48.

Shrader, R.C., and Simon, M., (1997), 'Corporate versus Independent New Ventures: Resource, Strategy and Performance Differences', Journal of Business Venturing 12(1): 47-66.

Thomsen, S. and Pedersen, T., (2000), 'Ownership Structure and Economic Performance in The Largest European Companies' Strategic Management Journal 21(6): 689-705. 